Preliminary Lifetime Predictions for

304 Stainless Steel as the LANL ABC

Blanket Material

John J. Park

John J. Buksa

Michael G. Houts

Edward D. Arthur 


\section{DISCLAIMER}

This report was prepared as an account of work sponsored by an agency of the linited States Government. Neither the United States Government nor any agency thereof, nor any of their employees, make any warranty, express or implied, or assumes any legal liability or responsibility for the accuracy, completeness, or usefulness of any information, apparatus, product, or process disclosed, or represents that its use would not infringe privately owned rights. Reference herein to any specific commercial product, process, or service by trade name, trademark, manufacturer, or otherwise does not necessarily constitute or imply its endorsement, recommendation, or favoring by the United States Government or any agency thereof. The views and opinions of authors expressed herein do not necessar. ily state or reflect those of the United States Government or any agency thereof. 


\section{DISCLAIMER}

Portions of this document may be illegible electronic image products. Images are produced from the best available original document. 


\section{Contents}

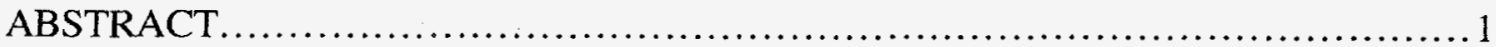

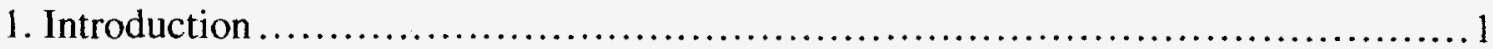

2. Lifetime for the ABC Stainless Steels.............................................

2.1. LANL ABC System...........................................................

2.2. Hastelloy $\mathrm{N}$ and Stainless Steels ......................................... 5

2.3. Lifetime of 304 Stainless Steel for ABC...................................... 6

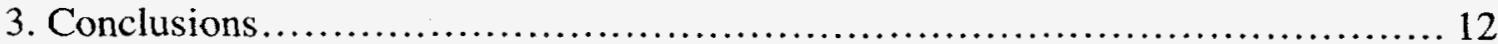

4. Acknowledgments........................................................ 13

5. References......................................................... 14 


\section{List of Tables}

Table 1. Flux calculations for the reference externally moderated $\mathrm{ABC}$ system. .........7

Table 2. Fluence limit for 304 stainless steel used for reference ABC system at different temperatures based on $10 \%$ residual ductility criterion. $\ldots \ldots \ldots \ldots \ldots \ldots \ldots . \ldots . \ldots$

Table 3. Fluence limit for 304 stainless steel used for reference ABC system at different temperatures based on $5 \%$ residual ductility criterion....

\section{List of Figures}

Figure 1. Fluence limit for 304 stainless steel based on $10 \%$ residual ductility..........2

Figure 2. Conceptual design of externally moderated ABC system....................4

Figure 3. Fluence limit for 304 stainless steel based on $5 \%$ residual ductility. ...........7

Figure 4. Expected lifetime of 304 stainless steel in reference ABC system based on $10 \%$ residual ductility criterion.

Figure 5. Expected lifetime of the 304 stainless steel in the reference ABC system based on $5 \%$ residual ductility. 


\title{
Preliminary Lifetime Predictions for 304 Stainless Steel as the LANL ABC Blanket Material
}

\author{
by \\ John J. Park, John J. Buksa, Michael G. Houts, and Edward D. Arthur
}

\begin{abstract}
The prediction of materials lifetime in the preconceptual Los Alamos National Laboratory (LANL) Accelerator-Based Conversion of Plutonium (ABC) is of utmost interest. Because Hastelloy $N$ showed good corrosion resistance to the Oak Ridge National Laboratory Molten Salt Reactor Experiment fuel salt that is similar to the LANL ABC fuel salt, Hastelloy $N$ was originally proposed for the LANL ABC blanket material. In this paper, the possibility of using 304 stainless steel as a replacement for the Hastelloy $\mathrm{N}$ is investigated in terms of corrosion issues and fluence-limit considerations. An attempt is made, based on the previous Fast Flux Test Facility design data, to predict the preliminary lifetime estimate of the 304 stainless steel used in the blanket region of the LANL ABC.
\end{abstract}

\section{Introduction}

The structural materials damage produced by intense neutron irradiation in the Los Alamos National Laboratory (LANL) Accelerator-Based Conversion of Plutonium (ABC) system (Bowman, 1995) is a major design consideration because of its effect in reducing materials lifetimes and the overall safety of the system. The materials properties considered in lifetime assessment are radiation swelling, tensile ductility and strength, radiation and thermal creep, and fatigue. These properties depend on many factors such as fluence, energy spectrum, temperature, and stress of the system. Assessment of the materials damage can be achieved by testing specimens subjected to the same or similar conditions as those found in the $\mathrm{ABC}$ environment; however, the experimental equipment needed to simulate this environment is extremely costly and limited in availability, and there is little data on proton irradiation damage of structural materials. On the other hand, there is quite a lot of data for neutron irradiation damage on structural materials. Therefore, materials lifetimes for the ABC environment can be estimated based on these data. In this paper, an attempt is made, based on Fast Flux Test Facility (FFTF) design data (Moen, Tobin, and Thomas, 1970), to create the preliminary lifetime estimates of the stainless steels used in the blanket region of a (bounding) example $\mathrm{ABC}$ design.

The cladding material for the FFTF is made of 316 stainless steel, and most of the structural components are made of 304 stainless steel. During the conceptual design of the FFTF, it was necessary to define realistic limits beyond which materials in the reactor system could not be subjected without seriously compromising the safety and efficiency of 
the reactor. A reasonable approach to developing a fluence-limit criterion would be to define a limit based on the residual mechanical properties at the end of the life of a component. Because all mechanical properties are not equally susceptible to neutroninduced degradation, it would not be necessary to assign specific reliability limits to each property. The approach used in the FFTF design was to determine the one critical mechanical property that is most sensitive to neutron exposure and to use it as a guide to define the maximum permissible fluence limit. After investigating the effects of neutron irradiation on the mechanical properties of 304 stainless steel, it was found that the ductility was affected most severely, and this parameter was adopted in determining fluence limit. Thus, an arbitrary fluence limit of $10 \%$ residual ductility at end of life was defined for the core barrel, core support structure, and reactor vessel. After representative ductility data was selected by the preset guidelines, and a master plot was obtained for a specific temperature, the fluence limit for 304 stainless steel at each temperature was obtained, as shown in Figure 1.

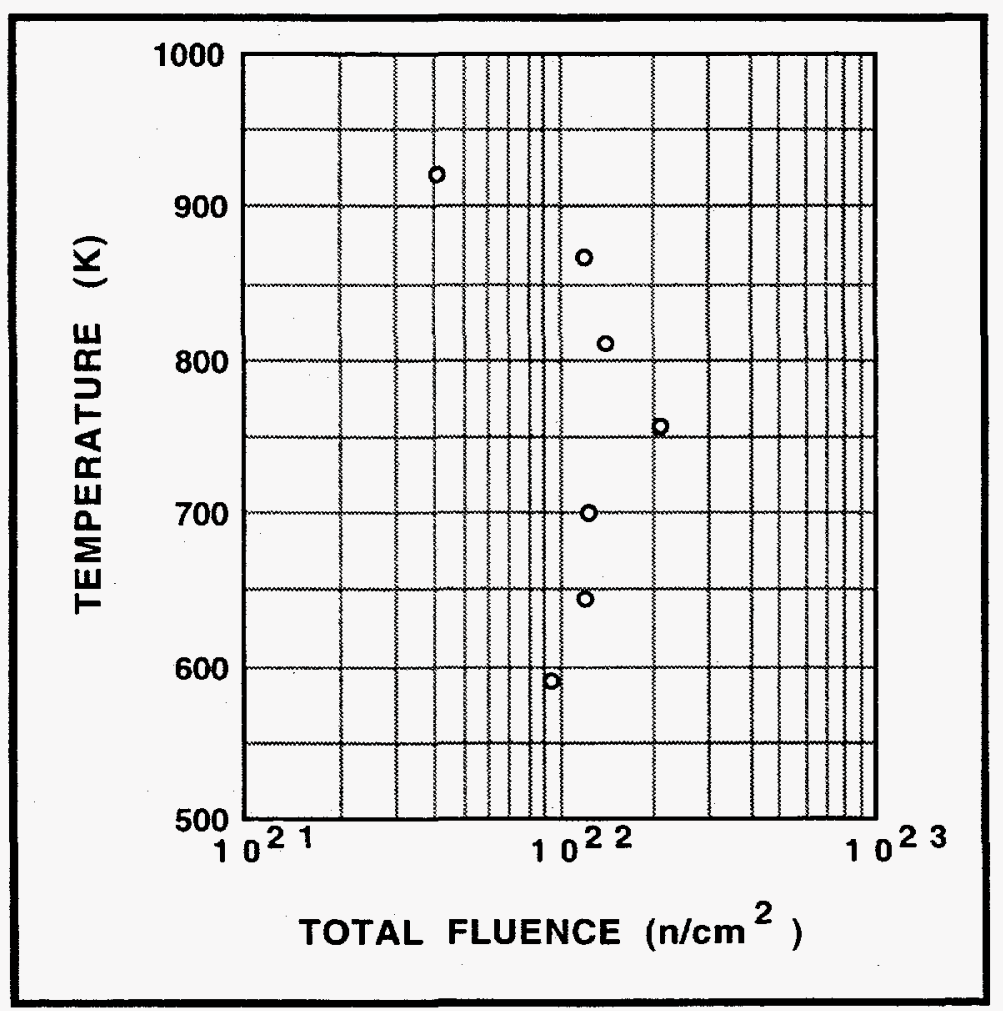

Figure 1. Fluence limit for 304 stainless steel based on $10 \%$ residual ductility. ${ }^{2}$ 


\section{Lifetime for the ABC Stainless Steels}

\subsection{LANL ABC System}

Under a study supported by the U.S. Department of Energy, design efforts have focused on two widely varying blanket concepts for an accelerator-based weapons plutonium burning application. Each system generally is described as a high-power spallation neutron source surrounded by a molten-salt blanket. One concept uses internal moderation and has design similarities to the Oak Ridge National Laboratory (ORNL) Molten Salt Breeder Reactor (MSBR) and the High-Temperature Gas-Cooled Reactor. A second concept, an externally moderated system, uses a small-volume, high-flux, central, salt-containing region surrounded by a graphite moderator. The second concept is the focus of this paper. Figure 2 shows the preconceptual design of the 500-MW th externally moderated LANL ABC system. In this system, the preconceptual target design is made of a liquid metal that is circulating through an active target region, where it converts $800-\mathrm{MeV}$ protons to low-energy neutrons by a spallation process and delivers them to the plutoniumbearing blanket. This design is unique in that the beam window is an integral part of the target containment structure and is convectively cooled by the flowing liquid metal.

Both concepts exhibit advantages and have issues associated with them. The internally moderated design is characterized by a low, soft neutron flux at the blanket baffle and vessel wall and by a moderate, mixed flux at the target sleeve. The externally moderated design is characterized by a highly hard neutron flux at the blanket, vessel, and target sleeve. Both achieved high burnup of total $\mathrm{Pu}$ and $\mathrm{Pu}-239$ (90\% and 98\%, respectively). For the externally moderated system, advantages include improved behavior of the reactivity temperature coefficient and lessening of waste disposal demands because of isolation of the graphite from the fuel salt. A major issue for the externally moderated system is the choice of materials for construction of the small-volume salt vessel and the lifetime required for their replacement. A target lifetime goal for components in high-flux regions is two years. Because Hastelloy $\mathrm{N}$ showed good corrosion resistance to the ORNL Molten Salt Reactor Experiment (MSRE) fuel salt that is similar to the LANL ABC fuel salt, Hastelloy $\mathrm{N}$ was originally proposed for the component material. Later, the possibility of using comercially available 304 stainless steel was investigated. The two main areas of concern were corrosion and fluence limits. From a materials-damage perspective, the externally moderated design offers the greatest (and bounding) constraints. 


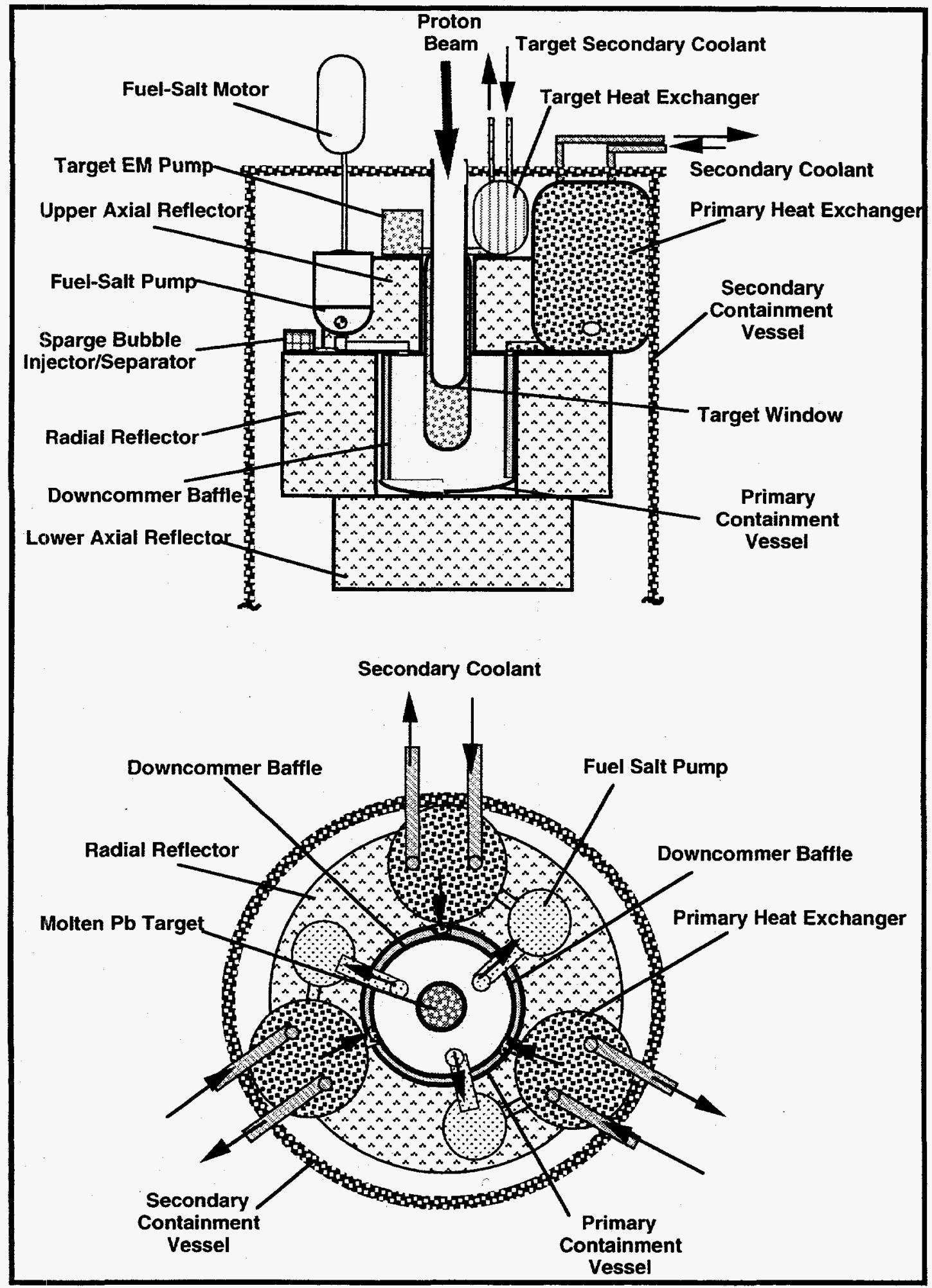

Figure 2. Conceptual design of externally moderated $A B C$ system. 


\subsection{Hastelloy $N$ and Stainless Steels}

Hastelloy $\mathrm{N}(\mathrm{Ni}-17 \mathrm{Mo}-7 \mathrm{Cr}-5 \mathrm{Fe}$ ) was developed during the MSRE program, and it showed excellent corrosion resistance to the MSRE fuel salt, $\mathrm{LiF}_{-} \mathrm{BeF}_{2}-\mathrm{ZrF}_{4}-\mathrm{UF}_{4}(65.0-$ 29.1-5.0-0.9 mole \%, respectively). It is a nickel-base alloy that is solution-strengthened with molybdenum and has an optimized chromium content to maximize oxidation resistance and to minimize corrosion by fluoride salts. The chromium content is low enough for the alloy to have excellent corrosion resistance to the salt, and it is high enough to impart good oxidation resistance in the cell atmosphere. The molybdenum content was adjusted to give good strength without an embrittling second phase. The mechanical property data were reviewed by the ASME Boiler and Pressure Vessel Code Committee. Code approval was obtained under Case 1315 for Unfired Pressure Vessel construction and Case 1345 for Nuclear Vessel construction. However, the MSRE program revealed two potential problems in the use of Hastelloy $\mathrm{N}$ for the more advanced MSBR, in which a more severe environment would be encountered. The first problem was that Hastelloy $\mathrm{N}$ showed helium embrittlement problems at elevated temperatures by an $(n, \alpha)$ reaction of nickel and residual boron with thermal neutrons. The second was that strained tensile specimens of Hastelloy $\mathrm{N}$ showed shallow-grain-boundary cracking after exposure to the MSRE fuel salt. The cause of the cracking was traced to penetration of fission-product tellurium along surfaceexposed grain boundaries. Later, it was found that this tellurium embrittlement effect was significantly decreased by adding $1-2 \%$ niobium to Hastelloy (modified Hastelloy $N$ ) or by keeping the $\mathrm{U}^{+4} / \mathrm{U}^{+3}$ concentration ratio (redox potential) in the salt below 30 . In addition, corrosion tests were conducted to reevaluate the possibility of using stainless steels as containment materials for the MSBR.

Since the beginning of the Nuclear Age, stainless steels have been used extensively as nuclear structural materials, and they have performed quite well. Stainless steels have a lower ( $n, \alpha$ ) cross section; consequently, they produce less radiation-induced helium embrittlement. They also are more resistant to tellurium embrittlement and are readily available at low cost. Thus, the assessment of stainless steels had been included in the MSBR program as an alternative containment material. However, the feasibility was not resolved before the program terminated. The main disadvantages of stainless steel are its lower service temperature and the requirement of a lower $U^{+4 / U^{+3}}$ ratio in the salt.

If a stainless steel was to be used in the LANL ABC design as a blanket material to hold the fuel salt, its corrosion behavior in the fuel salt and its fluence limit in intense radiation environments needed to be considered. During the MSRE program, 304L stainless steel was tested in $\mathrm{LiF}-\mathrm{BeF}_{2}-\mathrm{ZrF}_{4}-\mathrm{UF}_{4}-\mathrm{ThF}_{4}$ (70-23-5-1-1 mole \%, respectively) salt, similar to 
the $\mathrm{ABC}$ salt, in a thermal convection loop number 1258 with a maximum temperature of $677^{\circ} \mathrm{C}(950 \mathrm{~K})$ and minimum temperature of $588^{\circ} \mathrm{C}$ for 15,000 hours (1.7 years). The results showed a maximum attack of only 0.002 in. from the specimen surface (ORNL Report ORNL-TM-3872, 1965). After 45,724 hours (5.2 years) of salt exposure, the specimens showed voids extending for at least 10 mil into each side of each specimen (Koger, 1972). The corrosion behavior of stainless steel in the $\mathrm{LiF}_{-}-\mathrm{BeF}_{2}$ salt containing $\mathrm{PuF}_{3}$ in place of $\mathrm{UF}_{4}$ also will depend on the redox potential of the system. If the potential can be maintained at the same level as in the MSBR program, the corrosion rate of the stainless steel, in terms of chromium and iron oxidation, should be unaffected by the replacement. However, the oxidation potential at which the plutonium activity associated with $\mathrm{PuF}_{3}$ reaches unity is lower than the potential at which the activity of uranium associated with $\mathrm{UF}_{3}$ achieves unity. Accordingly, it may be possible to maintain a lower oxidation potential in the $\mathrm{PuF}_{3}$ salt than in the uranium salt without encountering alloying with the containment material (Devan, 1995). Based on the above information, it appears that 304 stainless steel may be applicable, from a corrosion perspective, for components with lifetimes on the order of two years.

The fluence-limit information seems to be the most important parameter in predicting the lifetime of $\mathrm{ABC}$ components. However, this information is not available for Hastelloy. The only information in the literature concluded without detailed explanation that the reactor vessel in the MSRE would have a minimum service life of 20,000 hours, or 2.28 years (Briggs, 1967). On the other hand, the fluence limit of 304 stainless steel in the conceptual FFTF design is available, as shown in Figure 3. To date, this is the only available fluencelimit information for stainless steels; thus it was used to estimate the lifetime of major $\mathrm{ABC}$ components.

\subsection{Lifetime of 304 Stainless Steel for ABC}

In the FFTF, the total flux is only $5-10 \%$ greater than its fast flux $(>0.1 \mathrm{MeV})$. In the LANL externally moderated $\mathrm{ABC}$ design, the total flux is estimated to be 5 to 10 times greater than the fast flux. Therefore, it was thought reasonable to use fast flux rather than total flux for the lifetime estimation of the $\mathrm{ABC}$ component. The fluxes for the reference externally moderated $\mathrm{ABC}$ system were calculated and are shown in Table 1 . In this calculation, the thickness of the target sleeve, the downcomer baffle, and the radial vessel were arbitrarily set at $3 \mathrm{~mm}, 1 \mathrm{~mm}$, and $3 \mathrm{~mm}$, respectively. The flux in the graphite started out roughly the same as in the steel vessel and decreased to negligible values at $1 \mathrm{~m}$. Based on the flux calculations in Table 1 and temperature-dependent, fluence-limit information in 
Figure 1, the estimated fluence limit of the 304 stainless steel components at different temperatures for the $\mathrm{ABC}$ system has been calculated. The results are shown in Table 2. The expected lifetime of the components at each flux based on the $10 \%$ residual ductility criterion is shown in Figure 4.

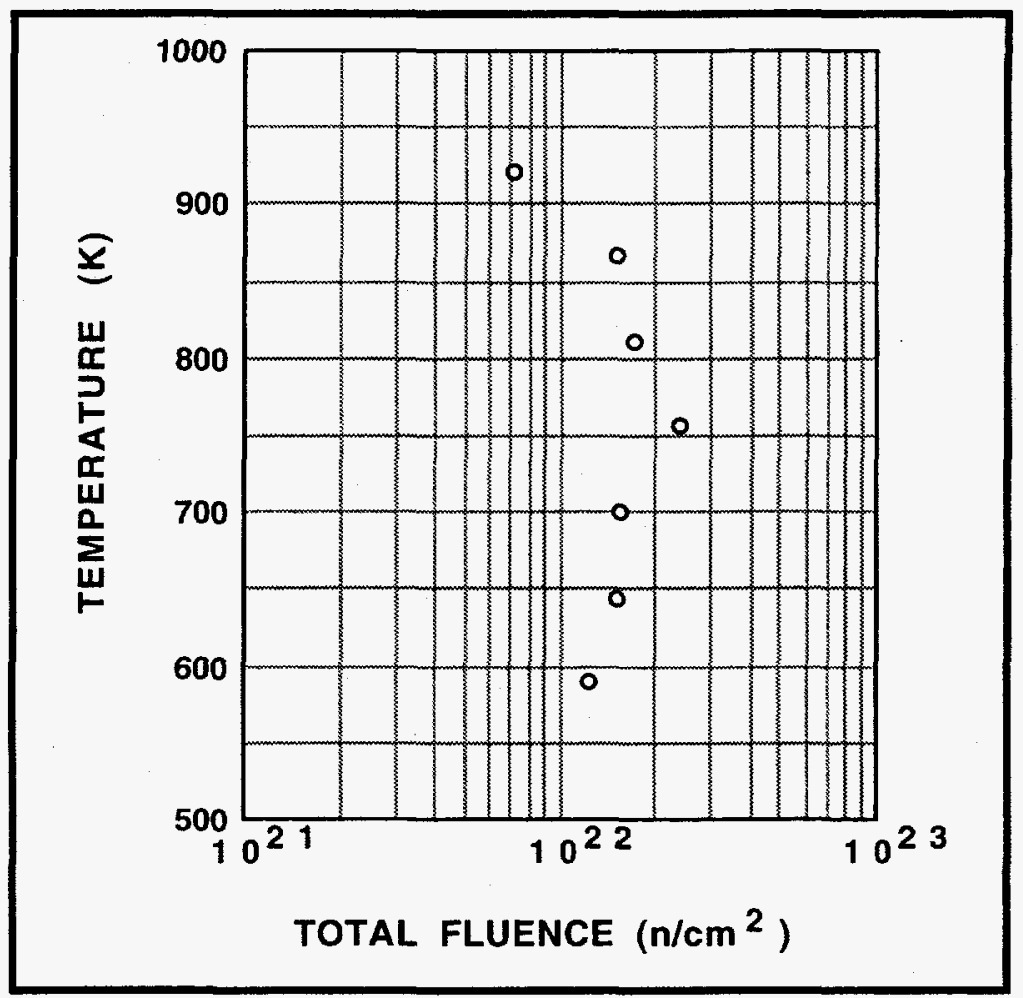

Figure 3. Fluence limit for 304 stainless steel based on 5\% residual ductility.

Table 1. Flux calculations for the reference externally moderated ABC system.

\begin{tabular}{||l|l|c|}
\hline $\begin{array}{c}\text { Surface } \\
\text { Number }\end{array}$ & \multicolumn{1}{|c|}{ Description } & Flux $\left(\mathrm{n} / \mathrm{cm}^{2}-\mathrm{s}\right)$ \\
\hline 101 & Target Surface & $9.40 \times 10^{14}$ \\
102 & Baffle & $1.03 \times 10^{15}$ \\
104 & Radial Vessel (Opposite Target=>Peak) & $6.90 \times 10^{14}$ \\
202 & Bottom of Vessel & $7.10 \times 10^{14}$ \\
203 & Bottom of Target & $1.10 \times 10^{15}$ \\
206 & Top of Target & $6.20 \times 10^{14}$ \\
\hline
\end{tabular}


Table 2. Fluence limit for 304 stainless steel used for reference ABC system at different temperatures based on $10 \%$ residual ductility criterion.

\begin{tabular}{|c|c|c|c|c|c|}
\hline $\begin{array}{l}\text { Surface } \\
\text { Number }\end{array}$ & Component & $\underset{\left(\mathrm{n} / \mathrm{cm}^{2}-\mathrm{s}\right)}{\text { Flux }}$ & Temp. (K) & Temp. $\left({ }^{\circ} \mathrm{C}\right)$ & $\begin{array}{l}\text { Fl. limit } \\
\left(\mathrm{n} / \mathrm{cm}^{2}\right)\end{array}$ \\
\hline \multirow[t]{4}{*}{101} & \multirow{4}{*}{$\begin{array}{l}\text { Target } \\
\text { surface }\end{array}$} & $9.40 \mathrm{E}+14$ & 900 & 627 & $6.00 \mathrm{E}+21$ \\
\hline & & $9.40 E+14$ & 850 & 577 & $1.00 \mathrm{E}+22$ \\
\hline & & $9.40 \mathrm{E}+14$ & 800 & 527 & $1.60 \mathrm{E}+22$ \\
\hline & & $9.40 \mathrm{E}+14$ & 750 & 477 & $1.80 \mathrm{E}+22$ \\
\hline \multirow[t]{4}{*}{102} & \multirow[t]{4}{*}{ Baffle } & $1.03 E+15$ & 900 & 627 & $6.00 E+21$ \\
\hline & & $1.03 E+15$ & 850 & 577 & $1.00 \mathrm{E}+22$ \\
\hline & & $1.03 E+15$ & 800 & 527 & $1.60 \mathrm{E}+22$ \\
\hline & & $1.03 E+15$ & 750 & 477 & $1.80 \mathrm{E}+22$ \\
\hline \multirow[t]{4}{*}{104} & \multirow{4}{*}{$\begin{array}{l}\text { Radial } \\
\text { vessel }\end{array}$} & $6.90 E+14$ & 900 & 627 & $6.00 \mathrm{E}+21$ \\
\hline & & $6.90 E+14$ & 850 & 577 & $1.00 E+22$ \\
\hline & & $6.90 \mathrm{E}+14$ & 800 & 527 & $1.60 \mathrm{E}+22$ \\
\hline & & $6.90 \mathrm{E}+14$ & 750 & 477 & $1.80 \mathrm{E}+22$ \\
\hline \multirow[t]{4}{*}{202} & \multirow{4}{*}{$\begin{array}{l}\text { Bottom } \\
\text { of } \\
\text { vessel }\end{array}$} & $7.10 \mathrm{E}+14$ & 900 & 627 & $6.00 \mathrm{E}+21$ \\
\hline & & $7.10 \mathrm{E}+14$ & 850 & 577 & $1.00 \mathrm{E}+22$ \\
\hline & & $7.10 \mathrm{E}+14$ & 800 & 527 & $1.60 \mathrm{E}+22$ \\
\hline & & $7.10 \mathrm{E}+14$ & 750 & 477 & $1.80 \mathrm{E}+22$ \\
\hline \multirow[t]{4}{*}{203} & \multirow{4}{*}{$\begin{array}{l}\text { Bottom } \\
\text { of } \\
\text { target }\end{array}$} & 1. $10 \mathrm{E}+15$ & 900 & 627 & $6.00 \mathrm{E}+21$ \\
\hline & & $1.10 \mathrm{E}+15$ & 850 & 577 & $1.00 \mathrm{E}+22$ \\
\hline & & 1. $10 \mathrm{E}+15$ & 800 & 527 & $1.60 \mathrm{E}+22$ \\
\hline & & $1.10 E+15$ & 750 & 477 & $1.80 \mathrm{E}+22$ \\
\hline \multirow[t]{4}{*}{206} & \multirow{4}{*}{$\begin{array}{l}\text { Top } \\
\text { of } \\
\text { target }\end{array}$} & $6.20 E+14$ & 900 & 627 & $6.00 \mathrm{E}+21$ \\
\hline & & $6.20 \mathrm{E}+14$ & 850 & 577 & $1.00 \mathrm{E}+22$ \\
\hline & & $6.20 \mathrm{E}+14$ & 800 & 527 & $1.60 \mathrm{E}+22$ \\
\hline & & $6.20 E+14$ & 750 & 477 & $1.80 \mathrm{E}+22$ \\
\hline
\end{tabular}




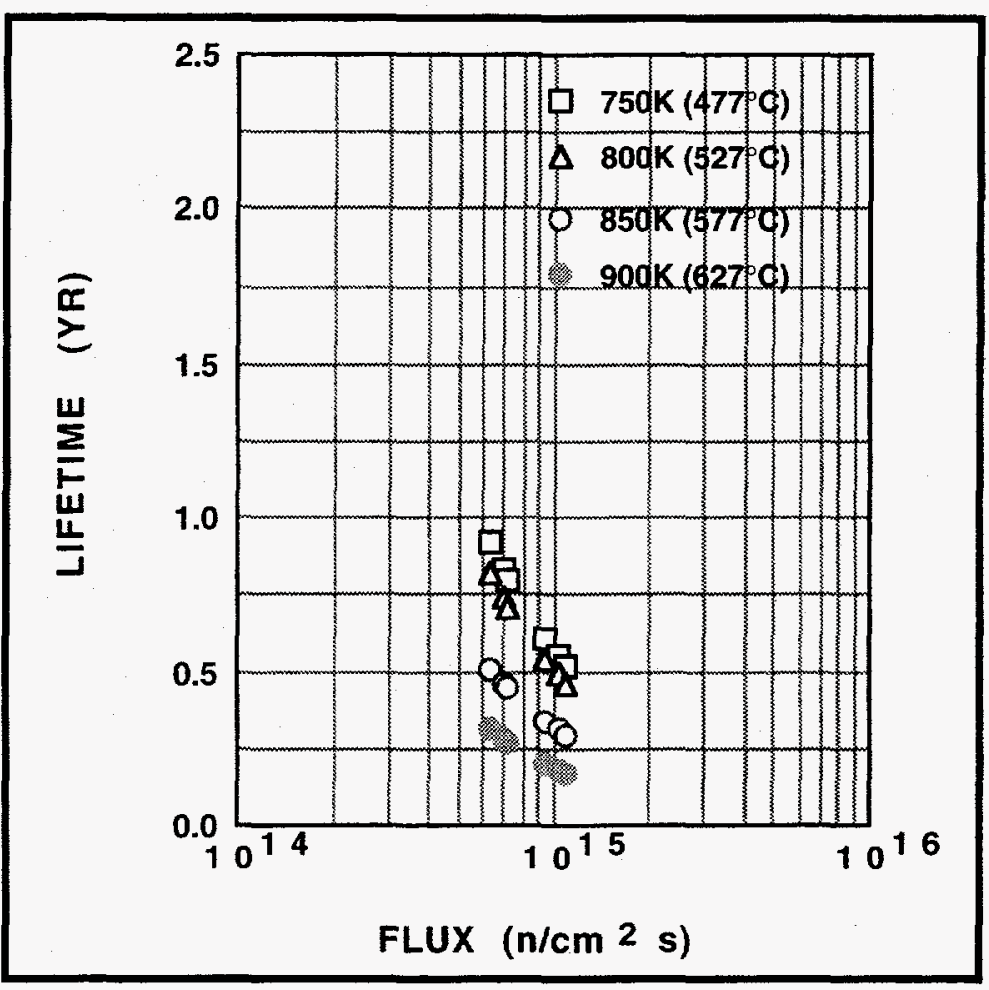

Figure 4. Expected lifetime of 304 stainless steel in reference ABC system based on $10 \%$ residual ductility criterion.

For the $\mathrm{ABC}$ system design, $10 \%$ ductility may be more than enough because not much stress is exerted on the salt containment vessel. Thus, the lifetime also was calculated based on a criterion of $5 \%$ residual ductility. The information given by Moen, Toben, and Thomas (1970) allowed us to obtain the fluence limit of the 304 stainless steel at $644^{\circ} \mathrm{K}$ based on $5 \%$ ductility. The data points at each temperature were shifted based on the assumption that the fluence limit will change in direct correlation to temperature changes. The resulting fluence limit for stainless steel using the $5 \%$ ductility criterion is shown in Figure 3. The expected fluence limits and lifetimes in the reference ABC system at each flux are shown in Table 3 and Figure 5, respectively. 
Table 3. Fluence limit for 304 stainless steel used for reference $\mathrm{ABC}$ system at different temperatures based on $5 \%$ residual ductility criterion.

\begin{tabular}{|c|c|c|c|c|c|}
\hline $\begin{array}{l}\text { Surface } \\
\text { Number }\end{array}$ & Component & $\underset{\left(\mathrm{n} / \mathrm{cm}^{2}-\mathrm{s}\right)}{\text { Flux }}$ & Temp. (K) & Temp. $\left({ }^{\circ} \mathrm{C}\right)$ & $\begin{array}{l}\text { Fl. Limit } \\
\left(\mathrm{n} / \mathrm{cm}^{2}\right)\end{array}$ \\
\hline \multirow[t]{4}{*}{101} & Target & $9.40 \mathrm{E}+14$ & 900 & 627 & $9.00 \mathrm{E}+21$ \\
\hline & surface & $9.40 \mathrm{E}+14$ & 850 & 577 & $1.80 \mathrm{E}+22$ \\
\hline & & $9.40 \mathrm{E}+14$ & 800 & 527 & $2.30 \mathrm{E}+22$ \\
\hline & & $9.40 \mathrm{E}+14$ & 750 & 477 & $3.00 \mathrm{E}+22$ \\
\hline \multirow[t]{4}{*}{102} & Baffle & $1.03 \mathrm{E}+15$ & 900 & 627 & $9.00 E+21$ \\
\hline & & $1.03 \mathrm{E}+15$ & 850 & 577 & $1.80 E+22$ \\
\hline & & $1.03 \mathrm{E}+15$ & 800 & 527 & $2.30 \mathrm{E}+22$ \\
\hline & & $1.03 \mathrm{E}+15$ & 750 & 477 & $3.00 E+22$ \\
\hline \multirow[t]{4}{*}{104} & Radial & $6.90 \mathrm{E}+14$ & 900 & 627 & $9.00 E+21$ \\
\hline & vessel & $6.90 \mathrm{E}+14$ & 850 & 577 & $1.80 \mathrm{E}+22$ \\
\hline & & $6.90 \mathrm{E}+14$ & 800 & 527 & $2.30 \mathrm{E}+22$ \\
\hline & & $6.90 \mathrm{E}+14$ & 750 & 477 & $3.00 \mathrm{E}+22$ \\
\hline \multirow[t]{4}{*}{202} & Bottom & $7.10 \mathrm{E}+14$ & 900 & 627 & $9.00 \mathrm{E}+21$ \\
\hline & & $7.10 \mathrm{E}+14$ & 850 & 577 & $1.80 E+22$ \\
\hline & vessel & $7.10 \mathrm{E}+14$ & 800 & 527 & $2.30 \mathrm{E}+22$ \\
\hline & & $7.10 \mathrm{E}+14$ & 750 & 477 & $3.00 \mathrm{E}+22$ \\
\hline \multirow[t]{4}{*}{203} & Bottom & $1.10 \mathrm{E}+15$ & 900 & 627 & $9.00 \mathrm{E}+21$ \\
\hline & & $1.10 \mathrm{E}+15$ & 850 & 577 & $1.80 \mathrm{E}+22$ \\
\hline & target & $1.10 \mathrm{E}+15$ & 800 & 527 & $2.30 \mathrm{E}+22$ \\
\hline & & $1.10 \mathrm{E}+15$ & 750 & 477 & $3.00 \mathrm{E}+22$ \\
\hline \multirow[t]{5}{*}{206} & Top & $6.20 \mathrm{E}+14$ & 900 & 627 & $9.00 \mathrm{E}+21$ \\
\hline & of & $6.20 \mathrm{E}+14$ & 850 & 577 & $1.80 E+22$ \\
\hline & target & $6.20 \mathrm{E}+14$ & 800 & 527 & $2.30 E+22$ \\
\hline & & $6.20 \mathrm{E}+14$ & 750 & 477 & $3.00 \mathrm{E}+22$ \\
\hline & & $6.20 \mathrm{E}+14$ & 750 & 477 & $3.00 E+22$ \\
\hline
\end{tabular}




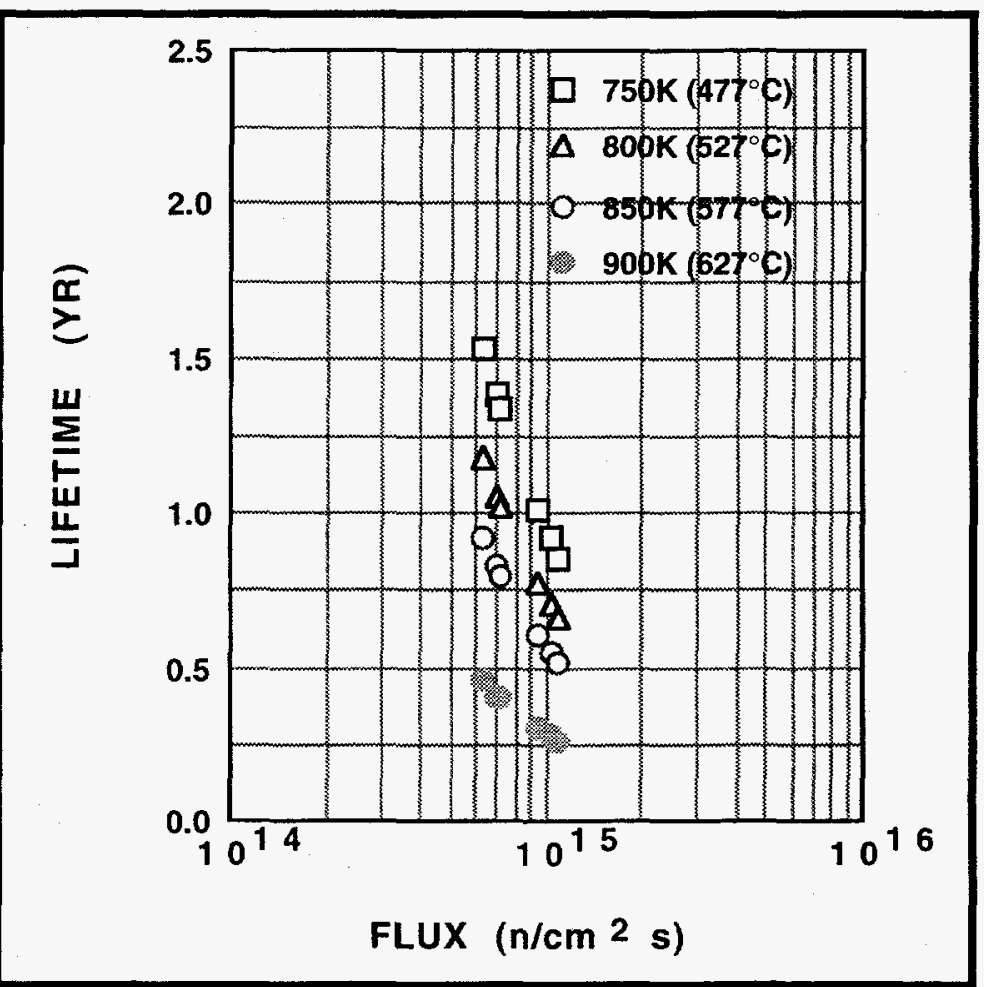

Figure 5. Expected lifetime of the 304 stainless steel in the reference ABC system based on $5 \%$ residual ductility.

Figures 3 and 5 show that the expected lifetimes of the components don't meet the present goal of replacing the components every two years. These figures also suggest that the lifetime will significantly increase as the temperatures and flux decrease. Thus, lowering the fuel salt temperature and decreasing the flux need to be considered. The flux also will change, depending on other system parameters. The actual fast and total flux at different components or walls depends on many design parameters, including the following:

- method of moderating the system (internally versus externally),

- modeling,

- modeling methodology,

- treatment of dependent flux, and

- design thickness.

The reference model used in the lifetime-limit calculation shown in Figure 4 and Tables 2 and 3 is the externally moderated system, which uses a small-volume, high-flux, central salt-containing region surrounded by a graphite moderator. As stated before, the externally 
moderated design is characterized by a highly hard neutron flux at the blanket, vessel, and target sleeve. The internally moderated design is characterized by a low, soft neutron flux at the blanket baffle and vessel wall and a moderate, mixed flux at the target sleeve.

Therefore, the expected lifetimes for the internally moderated system are longer than those for the externally moderated system. Depending on other design parameters, the lifetime may change significantly. Therefore, it should be emphasized that the data shown in Tables 2 and 3 and Figures 3 and 5 are tentative and are likely to change as the $\mathrm{ABC}$ system design moves forward.

The Moen, Tobin, and Thomas reference was published in 1970, and its data were generated during the 1950 s and 1960s. Also, the lifetime calculation used in this paper is dependent on only one reference. Since then, there has been a lot of effort to predict the lifetime of nuclear components, so a search should be conducted for a better fluence limit and for better lifetime data. In case 304 stainless steel turns out not to be adequate for the ABC system, other materials need to be considered.

One candidate is prime candidate alloy (PCA). PCA is a $14 \mathrm{Cr}-16 \mathrm{Ni}-2.5 \mathrm{Mo}-0.25 \mathrm{Ti}-$ $0.4 \mathrm{Si}-0.05 \mathrm{C}$ (all in weight percent) austenitic stainless steel whose composition was developed for void-swelling resistance in fusion applications. Modified PCA (PCA-B3) showed more resistance to helium embrittlement than PCA-A1 or -A3 after High Flux Isotope Reactor (HFIR) irradiation at $500^{\circ} \mathrm{C}$ and $600^{\circ} \mathrm{C}$ (Maziasz and Brasz, 1986). In this alloy, helium embrittlement was minimized by introducing fine carbide particles distributed in the matrix and grain boundaries. The helium bubbles were trapped by the carbide particles and did not grow to critical size for embrittlement. Another candidate material is HT-9 (Fe-12Cr-1 Mo-0.2C-0.4Si-0.5Ni-0.5Mn-0.3V-0.5W-0.02P-0.01S). HT-9 is a fusion reactor first-wall candidate material that has been tested extensively under neutron irradiation and has demonstrated excellent resistance to swelling after FFTF irradiation (Pinter, Hecht, and Trenchard, 1986).

\section{Conclusions}

The possibility of using 304 stainless steel for the LANL externally moderated ABC design has been investigated in terms of corrosion and fluence-limit considerations. Based on the previous results of corrosion tests performed at ORNL, it appears that 304 stainless steel may be applicable, from a corrosion perspective, for components with lifetimes on the order of two years. Fluence-limit data for the reference FFTF design were used for the lifetime calculations of the main $\mathrm{ABC}$ components for one arbitrarily fixed number of the externally moderated design, which is characterized by highly hard neutron flux at the blanket, vessel, and target sleeve. Using both $5 \%$ and $10 \%$ ductility criteria, we found that 
the lifetimes of the components for one example model of the externally moderated design did not meet our goal of two-year lifetimes.

The lifetime calculations used in this paper are dependent on only one reference. Since the reference was published, there has been a lot of effort to predict the lifetime of nuclear components, so a search should be conducted for a better fluence limit and for better lifetime data. In case 304 stainless steel turns out not to be adequate for the $\mathrm{ABC}$ system, other materials need to be considered. Candidate materials include Modified PCA (PCAB3) and HT-9, which demonstrated excellent resistance to swelling after HFIR and FFTF irradiation, respectively.

\section{Acknowledgments}

The authors would like to express thanks to Jack Devan, Jim DiStefano, Jim Keiser, and Ron Klueh from Oak Ridge National Laboratory for their helpful televideo discussion. 


\section{References}

1. C.D. Bowman, "Basis and Objectives of the Los Alamos Accelerator-Driven Transmutation Technology Project," in Proc. Int. Conf. on Accelerator-Driven Transmutation Technologies and Applications (AIP, New York, 1995), pp. 22-43.

2. A. Moen, J.C. Tobin, and K.C. Thomas, "Neutron Fluence Limit Determinations for Some Fast Flux Test Facility Components," in Irradiation Effects on Structural Alloys for Nuclear Reactor Applications, ASTM STP 484, (ASTM, 1970), pp. 409-418.

3. "Molten Salt Reactor Program Semiannual Progress Report for Period Ending August 31, 1965," Oak Ridge National Laboratory Report ORNL-TM-3872 (1965).

4. W. Koger, "Alloy Compatibility with $\mathrm{LiF}_{-} \mathrm{BeF}_{2}$ Salts Containing $\mathrm{ThF}_{4}$ and $\mathrm{UF}_{4}$," Oak Ridge National Laboratory Report ORNL-TM-4286 (1972).

5. H. Devan, J.R. DiStefano, W.P. Eatherly, J.R. Keiser, and R.L. Klueh, "Materials Consideration for Molten Salt Accelerator-based Plutonium Conversion Systems," in Proc. Int. Conf. on Accelerator-Driven Transmutation Technologies and Applications (AIP, New York, 1995), pp. 476-487.

6. B. Briggs, "Effects of Irradiation on the Service Life of the Molten-Salt Reactor Experiment," in Trans. of 1967 Ann. Meeting of Am. Nucl. Soc., Am. Nucl. Soc. 10 (1967), pp. 166-167.

7. J. Maziasz and D.N. Braski, "Modification of the Grain Boundary Microstructure of the Austenictic PCA Stainless Steel to Improve Helium Embrittlement Resistance," $J$. Nucl. Mater. 141-143 (1986), 973-977.

8. L. Pinter, S.L. Hecht, and R.G. Trenchard, "Nonswelling Behavior of HT9 Alloy Irradiated to High Exposure," Trans. of Am. Nucl. Soc. 69 (1993), 188-189. 